Dargut, T. ve Çelik, G. (2014). Türkçe öğretmeni adaylarının eğitimde teknoloji kullanımına ilişkin tutum ve düşünceleri. Ana Dili Eğitimi Dergisi, 2(2), 28-41.

Ana Dili Eğitimi Dergisi
Journal of Mother Tongue Education
ADED - JOMTE
www.anadiliegitimi.com

\title{
Türkçe Öğretmeni Adaylarının Eğitimde Teknoloji Kullanımına İlişkin Tutum ve Düşünceleri
}

\author{
Tülay Dargut* \\ Gamze Çelik $^{* *}$
}

\begin{abstract}
Özet
Bu çalışmanın amacı, Türkçe öğretmeni adaylarının öğretimde teknoloji kullanımına karşı tutum ve sahip oldukları fikirleri tespit etmektir ve bu doğrultuda, eğitimde daha etkili teknoloji kullanımına ilişkin yapılabilecekler konusunda önerilerde bulunmaktır. Bu araştırma betimsel bir çalışma olup, Çanakkale Onsekiz Mart Üniversitesi, Türkçe Öğretmenliği öğrencileri ile yürütülmüştür. Veriler, öğretimde teknolojik araçların kullanımına ilişkin öğrencilerin tutumlarının değerlendirildiği "Teknoloji Tutum Ölçeği" (Yavuz, 2005) ve yarı yapılandırılmış görüşme tekniği vasıtasıyla toplanmıştır. 19 sorudan oluşan Teknoloji Tutum Ölçeği ile 282 Türkçe öğretmeni adayından veri toplanmış ayrıca bu verileri desteklemek amacıyla Türkçe Öğretmenliği Bölümü’nden 5 öğrenci ile görüşme yapılmıştır. Araştırma bulgularına göre Türkçe Öğretmen adaylarının eğitimde teknoloji kullanımına ilişkin tutumlarının genel olarak olumlu olduğu, cinsiyet ile tutumlar arasında kadınlar lehine anlamlı bir ilişki olduğu, ancak sınıf düzeyi ve mezun oldukları okul yönünde anlamlı bir ilişki olmadığı anlaşılmıştır. Yapılan görüşmeler sonucunda da öğretmen adaylarının en çok öğrenmeyi kolaylaştırdığı için bilgisayar kullanımı yönünde olumlu düşünceye sahip oldukları görülmüştür.
\end{abstract}

Anahtar Kelimeler: Teknoloji, eğitim teknolojisi, Türkçe öğretmen adayı, tutum

\section{Pre-Service Turkish Language Teachers' Attitudes and Thoughts toward Use of Technology in Education}

\begin{abstract}
The aim of this study is determine attitudes and thoughts of Turkish Language Teacher Candidates toward using technology in education. This study was applied in 2012-2013 spring term at the department of Turkish Language Teacher Education at Çanakkale Onsekiz Mart University. The study was conducted with 282 students from Turkish Language Education Department. The data collection tool was the "Technology Attitude Scale" of 5 factors and 19 items, developed by Yavuz (2005). In addition, 5 students were chosen and semi-structured interview was conducted with them in order to determine students' ideas on the use of technology in education. According to the results of the study, the attitutes of the Turkish Language Education Teacher Candidates are positive in total. There is no significant difference toward class level and alma mater, but a significant difference was found between male and female teacher candidates that high in favor of female candidates. The data collected through the interviews showed that most teacher candidates have positive ideas on the use of computer because it facilitate education.
\end{abstract}

Keywords: Technology; education; pre-service Turkısh language teacher, attitude

\footnotetext{
${ }^{*}$ Arş. Gör.; Çanakkale Onsekiz Mart Üniversitesi, Eğitim Fakültesi, Bilgisayar ve Öğretim Teknolojileri Eğitimi Bölümü. E-posta: tdargut@gmail.com

** Arş. Gör.; Çanakkale Onsekiz Mart Üniversitesi, Eğitim Fakültesi, Ortaöğretim Sosyal Alanlar Eğitimi Bölümü. E-posta: gamzecelik@gmail.com
} 


\section{Giriş}

Bilim ve teknolojinin hızlı gelişimi, toplumun ihtiyaçlarını karşılayabilmesi için bu gelişime uyum sağlama gerekliliğini gündeme getirmektedir. Teknolojinin etkin bir şekilde kullanılması her alanda olduğu gibi eğitimde de büyük kolaylıklar ve üstünlükler sağlamaktadır. Eğitimde teknolojiden yararlanmanın sağladığı avantajlar arasında, çoklu öğrenme ortamlarının sağlanması, öğrenenlerin bireysel gereksinimlerinin karşılanması, dikkat çekerek öğrenenlerin derse ilgisini artırması yer almaktadır (Yalın, 2003: 82-83). Katrancı ve Uygun (2013: 773) da benzer şekilde eğitimde teknoloji kullanımının gerekliliğini vurgulayarak, dersi daha ilgi çekici hâle getirmesi, zaman kaybını önlemesi, hedefe ulaşmayı kolaylaştırması ve daha kalıcı öğrenmeyi sağlaması gibi üstünlüklerinden söz etmiştir. Dolayısıyla bu özellikler sağlandığında eğitim ortamlarında daha etkili ve kalıcı öğrenmenin sağlanması mümkün olacaktır. Bu bağlamda toplumda ihtiyaç duyulan nitelikli insan gücünü sağlayacak olan öğretmenlerin daha etkili bir eğitim için, teknolojiyi etkin bir şekilde kullanması zorunluluk hâline gelmiştir.

Gelişmekte olan bilgi toplumunda öğretmenlerin görevi sadece mevcut bilgiyi aktarmak değil, yenilikleri, gelişimleri sürekli takip ederek ve topladıkları verileri eleştirel bir bakış açısıyla yorumlayarak güncel ve doğru bilgileri öğrencilere aktarmaktır. Bu doğrultuda öğretmenlerin teknolojiyi eğitimde etkin bir şekilde kullanmalarının yanı sıra kendi gelişim süreçlerinde de teknolojiden yararlanarak kendilerini sürekli yenileyen bireyler olmaları gerekmektedir. Dolayısıyla öğretmen yetiştiren eğitim kurumlarının görevi, teknolojinin yaşamdaki önemini, eğitim sürecindeki gerekliliğini kavrayabilen, teknolojiyi eğitim öğretim sürecinde de etkili bir şekilde kullanma becerisine ve özgüvenine sahip öğretmen adayları yetiştirmek olmalıdır (Erdemir vd., 2009: 100).

Teknolojinin eğitim sürecini etkili hâle getirebilmesi için süreçte tek başına yer alması yeterli olmaz. Ancak öğretmenler teknolojiyi doğru bir şekilde, öğretim içerikleri ile bütünleşik olarak kullandıkları zaman etkili bir eğitim öğretim süreci sağlanabilir. Bu da öğretmenlerin bu konuda yeterli bilgi ve beceriye sahip olmasına bağlıdır (Koehler ve Mıshra, 2005: 132). Bireyleri, dili doğru kullanarak ve sesi sağlıklı üreterek kişilerarası iletişime hazırlayan, kelime hazinelerini geliştiren Türkçe derslerinde de öğretmenlerin teknolojiden yararlanarak hem kulağa hem göze hitap eden uygulamalı, aktif bir öğretim süreci sağlamaları önemlidir (Önkaş, 2008: 815).

Öğretmenlerin teknolojiye karşı bakış açıları onu derslerinde etkili ve verimli bir şekilde kullanabilmeleri için önemlidir (Çelik ve Kahyaoğlu, 2007: 573). Bu nedenle öğretmenlerin eğitim süreçlerinde teknolojiden yaralanmaları için öncelikli olarak teknolojiyi benimsemeleri, eğitim teknolojisindeki gelişimleri yakından takip etmeleri, bunun için de teknolojiye karşı olumlu tutum 
sergilemeleri gerekmektedir (Şahin ve Akçay, 2011: 910). Dolayısıyla, eğitimde teknolojinin etkili bir şekilde yer alabilmesi için öğretmen adaylarının teknolojiye yönelik olumlu ya da olumsuz tutumlarının belirlenmesi ve eğer olumsuz tutumlara sahiplerse bu doğrultuda önlemlerin alınması yararlı olacaktır (Çelik ve Kahyaoğlu, 2007: 571).

Sonuç olarak bu araştırmanın amacı Türkçe öğretmenliği bölümündeki öğretmen adaylarının eğitimde teknoloji kullanımına ilişkin tutumlarının belirlenmesi ve eğer tutumları olumsuz ise bu doğrultuda alınabilecek önlemler konusunda önerilerde bulunmaktır. Araştırmanın alt amaçları şu şekilde sıralanabilir:

1. Türkçe öğretmen adaylarının eğitimde teknoloji kullanımına ilişkin tutumlarını belirlemek.

2. Türkçe öğretmen adaylarının, cinsiyetleri, sınıf düzeyleri ve mezun olunan lise türü ile öğretimde teknoloji kullanımına ilişkin tutumları arasında anlamlı farklılık olup olmadığına ilişkin bulguları belirlemek.

3. Türkçe öğretmeni adaylarının, öğretimde teknoloji kullanımına ilişkin sahip oldukları fikirleri tespit etmek.

\section{Yöntem}

\section{Araştırma Modeli}

Araştırma betimsel nitelikte bir çalışmadır ve bu çalışmada tarama modeli kullanılmıştır. Karasar'a (2007) göre; “ Tarama modelleri; geçmişte ya da halen varolan bir durumu varolduğu şekliyle betimlemeyi amaçlayan araştırma yaklaşımlarıdır." Bu araştırmada da amaç, Türkçe Öğretmenliği Bölümü’ndeki öğrencilerin eğitimde teknoloji kullanımına ilişkin tutumlarını belirlemek olduğu için mevcut durum açıklanmaya ve bu doğrultuda yapılabilecekler konusunda öneriler verilmeye çalışımıştır. Dolayısıyla araştırmada tarama modeli kullanılmıştır. Ayrıca verileri desteklemek amacıyla Türkçe Öğretmenliği Bölümü’nden beş öğrenci ile yarı yapılandırılmış görüşme yapılmıştır.

\section{Evren ve Örneklem}

Araştırmada ulaşılabilir evren ele alınmıştır. Ulaşılabilir evren, araştırmacının hedef evren içerisindeki ulaşabildiği evreni temsil eder ve araştırma bu ulaşılabilir evrene genellenir (Fraenkel vd., 2012: 92). Bu araştırmanın ulaşılabilir evrenini, Çanakkale Onsekiz Mart Üniversitesi, Türkçe Öğretmenliği Bölümü'ndeki 282 öğretmen adayı oluşturmaktadır. Ayrıca, Türkçe Öğretmenliği 
Bölümü’nden 5 öğretmen adayı ile yarı yapılandırılmış görüşme yapılmıştır. Araştırmaya katılan Türkçe Öğretmen adaylarının kişisel özellikleri Tablo-1'de gösterilmiştir.

Tablo 1. Türkçe Öğretmeni Adaylarının Kişisel Özellikleri

\begin{tabular}{lll}
\hline Özellik & $\mathrm{F}$ & $\%$ \\
\hline Cinsiyet & 103 & 36,5 \\
Erkek & 179 & 63,5 \\
Kadın & 282 & 100 \\
TOPLAM & & \\
\hline Mezun olduğu lise türü & 157 & 55,7 \\
Genel Lise & 83 & 29,4 \\
Anadolu Lisesi & 16 & 5,7 \\
Anadolu Öğretmen Lisesi & 26 & 9,2 \\
Diğer & 282 & 100 \\
TOPLAM & & \\
\hline Sınıf düzeyi & & 19,9 \\
1. Sınıf & 56 & 31,2 \\
2. Sınıf & 88 & 30,1 \\
3. Sınıf & 85 & 18,8 \\
4. Sınıf & 53 & 100 \\
TOPLAM & 282 & \\
\hline & & \\
\hline
\end{tabular}

Araştırmaya katılan öğretmen adaylarının \%36,5'i (103) erkek, \%63,5'i (179) kadındır. Katılımcıların mezun oldukları lise türlerine bakıldığında \%55,7'si (157) genel lise, \%29,4'ü (83) Anadolu lisesi, \%5,7'si (16) Anadolu öğretmen lisesi ve \%9,2'si (26) diğer lise türlerinden mezun oldukları görülmektedir. Sınıf düzeylerine bakıldığında katılımcıların \%19,9'u (56) 1.sınıf, \%31,2'si (88) 2.sınıf, \%30,1'i (85) 3.sınıf ve \%18,8'i (53) 4.sınıf öğrencilerinden oluşmaktadır.

\section{Veri Toplama Araçları}

Veriler, öğretimde teknolojik araçların kullanımına ilişkin öğrencilerin tutumlarının değerlendirildiği "Teknoloji Tutum Ölçeği" (Yavuz, 2005) ve yarı yapılandırılmış görüşme tekniği vasıtasıyla toplanmıştır. 19 maddeden oluşan Teknoloji Tutum Ölçeği, "teknolojik araçların eğitim 
alanında kullanılmama durumu, teknolojik araçların eğitim alanında kullanılma durumu, teknolojinin eğitim yaşamına etkileri, teknolojik araçların kullanımının öğretilmesi ve teknolojik araçların değerlendirilmesi" isimli beş alt başıık içermektedir. Ölçeğin güvenirlik katsayısı orijinalinde 0, 8668 olarak bulunmuştur. Bu çalışmada ölçme aracının güvenirlik katsayısı Cronbach Alpha yöntemi ile hesaplanmış ve testin güvenirlik katsayısı 0,91 olarak bulunmuştur (Yavuz, 2005: 17).

Teknoloji Tutum Ölçeğinde yer alan maddeler, "kesinlikle katılıyorum" (5), "katılıyorum" (4), "kararsızım" (3), "katılmıyorum" (2) ve "kesinlikle katılmıyorum" (1) şeklinde ifade edilen beşli derecelendirme ile değerlendirilmiştir. Buna göre, elde edilen verilerde olumlu maddelerin seçeneklerine sırasıyla 5'den 1'e kadar bir değer verilerek, olumsuz maddelerin seçenekleri ise ters çevrilerek sırasıyla 1'den 5'e kadar bir değer ile kodlanmıştır. Yavuz (2005) tarafından geliştirilen “Teknoloji Tutum Ölçeği”nden elde edilen en yüksek toplam puan olan 71 en olumlu tutumların; en düşük toplam puan olan 43 ise en olumsuz tutumların göstergesi olarak belirtilmiştir. "kararsızım" seçeneği işaretlenerek elde edilebilecek en yüksek toplam puan olan 57 de yönü belli olmayan nötr durumların göstergesidir. Yani 58 puanın üzerindeki puanlar olumlu tutumlara, 56 puanın altındaki puanlar olumsuz tutumlara yöneliktir.

Beş açık uçlu sorudan oluşan yarı yapılandırılmış görüşme formu araştırmacılar tarafından oluşturulmuştur. Görüşme öncesinde araştırmacılar tarafından hazırlanan sorular aşağıda verilmiştir.

1. Size göre eğitimde kullanılan teknolojik araçlardan hangileri daha etkilidir?

2. Teknolojiyi eğitimde daha çok hangi amaçlarla kullanırsınız?

3. Teknolojinin eğitimde kullanılmasının olumsuz yönleri var mıdır? Eğer varsa size göre bunlar nelerdir?

4. Eğitimde teknoloji kullanımına ilişkin yeterliklerin gelişmesi için, başka ne tür çalışmalar yapılabilir?

5. Teknoloji ve eğitim kavramları arasındaki ilişkiyi bir metaforla açıklayınız.

\section{Verilerin Toplanması}

Çalışma 2012-2013 eğitim-öğretim yılı bahar döneminde, Çanakkale Onsekiz Mart Üniversitesi Türkçe Eğitimi Bölümü öğrencileriyle yapılmıştır. Öğretmen adaylarının eğitimde teknoloji kullanımına ilişkin tutumlarını belirlemek amacıyla kullanılan ölçek bizzat araştırmacılar tarafından öğretmen adaylarına uygulanmıştır. Sonrasında araştırmacılar tarafından oluşturulan yarı yapılandırılmış görüşme formu beş öğrenciye araştırmacılar tarafından uygulanmıştır. 


\section{Verilerin Analizi}

Araştırma sonucunda elde edilen veriler SPSS paket istatistik programından faydalanılarak, bilgisayar ortamında değerlendirilmiştir. Elde edilen veriler değerlendirilirken demografik bilgiler bölümünde yer alan değişkenler (cinsiyet, sınıf düzeyi, mezun olunan lise) için betimsel istatistik (frekans, yüzde) hesaplamaları yapılmıştır. Öğretmen adaylarının eğitimde teknoloji kullanımına ilişkin tutumlarının cinsiyete göre anlamlı bir farklılık gösterip göstermediğine ilişkin bulgular t testi ile belirlenmiştir. Türkçe öğretmeni adaylarının eğitimde teknoloji kullanımına ilişkin tutumlarının, sınıf düzeyi ve mezun oldukları lise türüne göre anlamlı bir farklılık olup olmadığı da ANOVA F testi ile belirlenmiştir. $\mathrm{Bu}$ analiz sonuçları değerlendirilirken verilerin yorumlanmasında $p<0,05$ olarak görüldüğünde gruplar arasında anlamlı bir fark olduğuna yönelik yorum yapılmıştır. Ayrıca, beş öğretmen adayının yarı yapılandırılmış görüşme formuna vermiş oldukları yanıtlar bilgisayar ortamına aktarıımış ve araştırmacılar tarafından ayrı ayrı okunarak kodlanmış, sonuçlar birleştirilerek analizleri yapılmıştır.

\section{Bulgular}

$\mathrm{Bu}$ bölümde çalışmanın temel amacına uygun olarak araştırma kapsamındaki Türkçe öğretmeni adaylarından toplanan veriler düzenlenmiştir. Araştırmanın alt amaçlarından biri "Türkçe öğretmen adaylarının eğitimde teknoloji kullanımına ilişkin tutumlarını belirlemek" tir. Bu doğrultuda uygulanan Teknoloji Tutum Ölçeği'ne ilişkin araştırma bulguları Tablo-2'de gösterilmiştir.

Tablo 2. Türkçe Öğretmeni Adaylarının Eğitimde Teknoloji Kullanımına iliş̧kin Tutumları

\begin{tabular}{|c|c|c|c|c|c|c|c|c|c|c|c|c|}
\hline \multirow[t]{2}{*}{ Ölçek Maddeleri } & \multicolumn{2}{|c|}{ 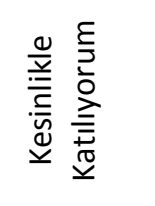 } & \multicolumn{2}{|c|}{ 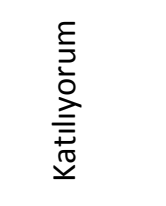 } & \multicolumn{2}{|c|}{$\begin{array}{l}\frac{E}{N} \\
\frac{N}{\omega} \\
\frac{\pi}{\pi} \\
\frac{\pi}{\sqrt{0}} \\
\frac{1}{n}\end{array}$} & \multicolumn{2}{|c|}{ 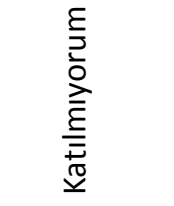 } & \multicolumn{2}{|c|}{ 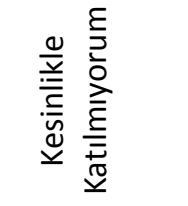 } & \multirow[t]{2}{*}{$\bar{X}$} & \multirow[t]{2}{*}{$\mathrm{S}$} \\
\hline & $f$ & $\%$ & $f$ & $\%$ & $f$ & $\%$ & $f$ & $\%$ & $f$ & $\%$ & & \\
\hline $\begin{array}{l}\text { 1. E-posta ile sadece } \\
\text { iletişim sağlanır, } \\
\text { eğitim alanında } \\
\text { kullanılamaz. }\end{array}$ & 15 & 5,3 & 31 & 11 & 22 & 7,8 & 99 & 35,1 & 115 & 40,8 & 3,95 & 1,18 \\
\hline
\end{tabular}


Tablo 2. (Devamı) Türkçe Öğretmeni Adaylarının Eğitimde Teknoloji Kullanımına Ilişskin Tutumları

\begin{tabular}{|c|c|c|c|c|c|c|c|}
\hline Ölçek Maddeleri & 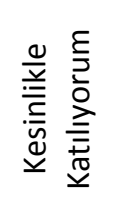 & 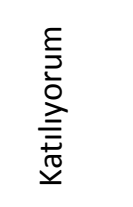 & 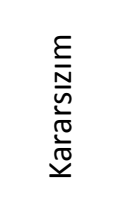 & 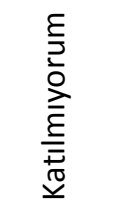 & 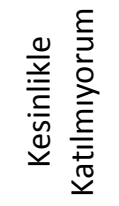 & $\bar{X}$ & $\mathrm{~S}$ \\
\hline & $\%$ & $\%$ & $\begin{array}{ll}f & \%\end{array}$ & $\begin{array}{l}f \\
\end{array}$ & $f$ & & \\
\hline
\end{tabular}

2. Tepegöz, slayt, projeksiyon gibi cihazlar kullanılırken fazla zaman harcanması nedeniyle tercih edilmemelidir.

3. Internet'in öğretim sürecinde kullanımı zaman kaybından $\begin{array}{llllllllllll}17 & 6,0 & 15 & 5,3 & 11 & 3,9 & 97 & 34,4 & 142 & 50,4 & 4,17 & 1,12\end{array}$ başka bir şey değildir.

\section{Teknolojik} araçların kullanılmasının öğrenci

motivasyonuna bir etkisi olmaz.

\section{Teknolojik} araçların dersin anlatımında kullanılması gerekmez.

6. Kamera ile dersin belirli bölümlerinin videoya kayıt edilmesi, öğrencilerin eksiklerini ve hatalarını görmelerini sağlar.

7. Videobantlarının tekrar izlenebilmesi özelliği öğrencilere geri bildirim sağlar.

8. Teknolojik araçlar alıştırma yapma ve tekrar amaçı kullanılabilir. 
Tablo 2. (Devamı) Türkçe Öğretmeni Adaylarının Eğitimde Teknoloji Kullanımına iliş̧kin Tutumları

\begin{tabular}{|c|c|c|c|c|c|c|c|c|c|c|c|c|}
\hline \multirow[t]{2}{*}{ Ölçek Maddeleri } & \multicolumn{2}{|c|}{ 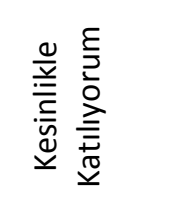 } & \multicolumn{2}{|c|}{ 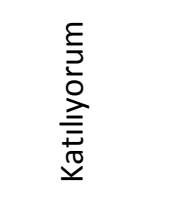 } & \multicolumn{2}{|c|}{ 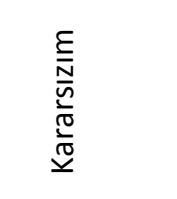 } & \multicolumn{2}{|c|}{ 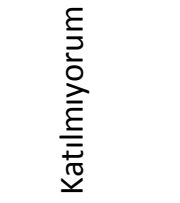 } & \multicolumn{2}{|c|}{ 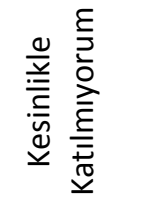 } & \multirow[t]{2}{*}{$\bar{X}$} & \multirow[t]{2}{*}{$S$} \\
\hline & $f$ & $\%$ & $f$ & $\%$ & $f$ & $\%$ & $f$ & $\%$ & $f$ & $\%$ & & \\
\hline $\begin{array}{l}\text { 9. Öğrencilere } \\
\text { bilgisayar } \\
\text { okuryazarlığı } \\
\text { hakkında temel } \\
\text { dersler verilmelidir. }\end{array}$ & 122 & 43,3 & 102 & 36,2 & 20 & 7,1 & 21 & 7,4 & 17 & 6,0 & 4,03 & 1,16 \\
\hline $\begin{array}{l}\text { 10. Mevcut } \\
\text { teknolojilerin } \\
\text { kullanımı, yeni } \\
\text { başka teknolojilerin } \\
\text { gelişmesine olanak } \\
\text { sağlar. }\end{array}$ & 116 & 41,1 & 119 & 42,2 & 13 & 4,6 & 15 & 5,3 & 19 & 6,7 & 4,05 & 1,13 \\
\hline $\begin{array}{l}\text { 11. Verimli çalışma } \\
\text { ve öğrenme } \\
\text { konusunda, } \\
\text { teknolojinin getirdiği } \\
\text { imkanlar olumlu bir } \\
\text { etkiye sahiptir. }\end{array}$ & 102 & 36,2 & 119 & 42,2 & 27 & 9,6 & 19 & 6,7 & 15 & 5,3 & 3,97 & 1,09 \\
\hline $\begin{array}{l}\text { 12. Teknoloji } \\
\text { kullanımı ile } \\
\text { anlaşılmasında } \\
\text { güçük çekilen } \\
\text { derslerin } \\
\text { kavranması daha } \\
\text { kolay hâle } \\
\text { gelecektir. }\end{array}$ & 90 & 31,9 & 126 & 44,7 & 34 & 12,1 & 18 & 6,4 & 14 & 5,0 & 3,92 & 1,06 \\
\hline $\begin{array}{l}\text { 13. Hayatta başarılı } \\
\text { olmak için mutlaka, } \\
\text { teknoloji } \\
\text { imkanlarından } \\
\text { yararlanmak } \\
\text { gerekmiyor. }\end{array}$ & 34 & 12,1 & 81 & 28,7 & 74 & 26,2 & 61 & 21,6 & 32 & 11,3 & 2,91 & 1,19 \\
\hline $\begin{array}{l}\text { 14. Günlük ve yıllık } \\
\text { planlar, öğretmenler } \\
\text { tarafından bilgisayar } \\
\text { kullanılarak } \\
\text { hazırlanmalıdır. }\end{array}$ & 65 & 23,0 & 123 & 43,6 & 60 & 21,3 & 25 & 8,9 & 9 & 3,2 & 3,74 & 1,01 \\
\hline $\begin{array}{l}\text { 15. Ders sırasında } \\
\text { sık sık bilgisayar } \\
\text { destekli öğretime } \\
\text { yer verilmelidir. }\end{array}$ & 56 & 19,9 & 118 & 41,8 & 68 & 24,1 & 27 & 9,6 & 13 & 4,6 & 3,62 & 1,05 \\
\hline
\end{tabular}


Tablo 2. (Devamı) Türkçe Öğretmeni Adaylarının Eğitimde Teknoloji Kullanımına iliş̧kin Tutumları

\begin{tabular}{|c|c|c|c|c|c|c|c|c|c|c|c|c|}
\hline \multirow[t]{2}{*}{ Ölçek Maddeleri } & \multicolumn{2}{|c|}{ 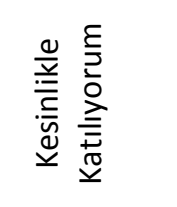 } & \multicolumn{2}{|c|}{ 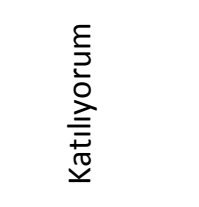 } & \multicolumn{2}{|c|}{ 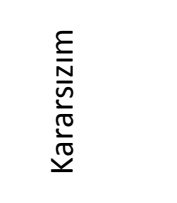 } & \multicolumn{2}{|c|}{ 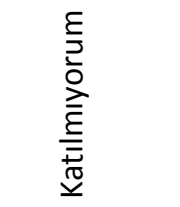 } & \multicolumn{2}{|c|}{ 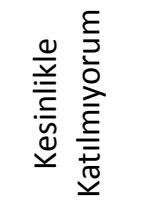 } & \multirow[t]{2}{*}{$\bar{X}$} & \multirow[t]{2}{*}{$\mathrm{S}$} \\
\hline & $f$ & $\%$ & $f$ & $\%$ & $f$ & $\%$ & $f$ & $\%$ & $f$ & $\%$ & & \\
\hline $\begin{array}{l}\text { 16. Öğrencilere yen } \\
\text { teknolojilerin } \\
\text { kullanımı hakkında } \\
\text { ön bilgiler } \\
\text { verilmelidir. }\end{array}$ & 111 & 39,4 & 121 & 42,9 & 19 & 6,7 & 17 & 6,0 & 14 & 5,0 & 4,05 & 1,07 \\
\hline $\begin{array}{l}\text { 17. Öğretmen } \\
\text { yetiştirmede yeni } \\
\text { teknolojilerin } \\
\text { kullanımı } \\
\text { artırılmalıdır. }\end{array}$ & 113 & 40,1 & 114 & 40,4 & 21 & 7,4 & 19 & 6,7 & 15 & 5,3 & 4,03 & 1,10 \\
\hline $\begin{array}{l}\text { 18. Teknolojik } \\
\text { araçlar ancak tüm } \\
\text { duyu organlarına } \\
\text { hitap ettiğinde } \\
\text { başarılı olur. }\end{array}$ & 78 & 27,7 & 104 & 36,9 & 66 & 23,4 & 19 & 6,7 & 15 & 5,3 & 3,74 & 1,09 \\
\hline $\begin{array}{l}\text { 19. Üniversiteden } \\
\text { mezun olabilmek } \\
\text { için, "Konu alanı ile } \\
\text { ilgili teknolojik } \\
\text { materyalleri } \\
\text { kullanabilme } \\
\text { yeterligigi" de } \\
\text { oranlanmalıdır. }\end{array}$ & 82 & 29,1 & 111 & 39,4 & 53 & 18,8 & 28 & 9,9 & 8 & 2,8 & 3,81 & 1,04 \\
\hline
\end{tabular}

Tutum ölçeğinden elde edilen verilere göre öğretmen adayları, tepegöz, slayt, projeksiyon gibi cihazlar kullanılırken fazla zaman harcanması nedeniyle tercih edilmemesi gerektiğine kesinlikle katılmamışlardır $(X=4,03)$. “Internet'in öğretim sürecinde kullanımı zaman kaybından başka bir şey değildir" maddesine katıımcıların \%50,4'ü "Kesinlikle katılmıyorum" yanıtını vermiştir $(X=4,17)$. Öğretmen adaylarının \%41,8'i teknolojik araçların kullanılmasının öğrenci motivasyonuna bir etkisi olmadığına kesinlikle katılmadıklarını ifade etmişlerdir $(X=4,02)$. "Teknolojik araçların dersin anlatımında kullanılması gerekmez" maddesine \%51,1 katılımcı olumsuz yanıt vererek kesinlikle katılmadıklarını belirtmişlerdir $(X=4,18)$. “Öğrencilere bilgisayar okuryazarlığı hakkında temel dersler verilmelidir" maddesine öğretmen adaylarının \%43,3'ü "Kesinlikle katılıyorum" yanıtını vermiştir $(X=4,03)$. Araştırmaya katılan öğretmen adaylarının "Mevcut teknolojilerin kullanımı, yeni başka teknolojilerin gelişmesine olanak sağlar" maddesine yanıtı \%41,1'i “Kesinlikle katılıyorum”, \%42,2'si 
"Katılıyorum" şeklinde olmuştur ( $\mathrm{X}=4,05)$. "Öğrencilere yeni teknolojilerin kullanımı hakkında ön bilgiler verilmelidir" maddesine katılımcıların \%39,4'ü "Kesinlikle katılıyorum" yanıtını verirken $\% 42,9$ 'u da katıldığını belirtmiştir $(X=4,05)$. Katılımcılar, öğretmen yetiştirmede yeni teknolojilerin kullanımının artırılması konusuna eşit derecede "Kesinlikle katılıyorum" ve "Katılıyorum" yanıtlarını vermişlerdir $(X=4,03)$.

"Türkçe öğretmen adaylarının, cinsiyetleri, sınıf düzeyleri ve mezun olunan lise türü ile öğretimde teknoloji kullanımına ilişkin tutumları arasında farklılık olup olmadığına ilişkin bulguları belirlemek." Araştırmanın ikinci alt amacını oluşturmaktadır. Bu amaca ilişkin bulgular Tablo-3, Tablo4 ve Tablo-5'de gösterilmiştir.

Tablo 3. Türkçe Öğretmeni Adaylarının Cinsiyetleri ile Teknoloji Kullanımına Ilişsin Tutumları Arasındaki ilişski

\begin{tabular}{lccccccc}
\hline & Cinsiyet & $\mathrm{N}$ & $\bar{X}$ & $\mathrm{~S}$ & $\mathrm{sd}$ & $\mathrm{t}$ & $\mathrm{p}$ \\
\hline \multirow{2}{*}{ Yeterlilik Düzeyi } & Kadın & 179 & 71.40 & 11.00 & \multirow{2}{*}{280} & 2.68 & .008 \\
& Erkek & 103 & 67.16 & 15.39 & & & \\
\hline
\end{tabular}

${ }^{*} \mathrm{p}<, 05$

Tablo-3'te belirtildiği gibi, 179 kadın ve 103 erkek Türkçe Öğretmen adayından oluşan katılımcıların cinsiyetleri ile teknoloji kullanımına ilişkin tutumları arasındaki ilişkiye bakıldığında kadınlar lehine anlamlı bir farklılık olduğu görülmüştür $[\mathrm{t}(280)=2.68, \mathrm{p}<, 05]$. Bu veriler doğrultusunda kadın öğretmen adaylarının $(X=71,40)$, erkek öğretmen adaylarına $(X=67,16)$ göre eğitimde teknoloji kullanımına ilişkin daha olumlu tutuma sahip olduğu sonucuna ulaşılmıştır.

Tablo 4. Türkçe Öğretmeni Adaylarının Sınıf Düzeyleri Ile Teknoloji Kullanımına İlişkin Tutumları Arasındaki iliş̧ki

\begin{tabular}{llllllll}
\hline Alt Boyutlar & $\begin{array}{l}\text { Varyansın } \\
\text { Kaynağı }\end{array}$ & $\begin{array}{l}\text { Kareler } \\
\text { Toplamı }\end{array}$ & $\begin{array}{l}\text { Serbestlik } \\
\text { Derecesi }\end{array}$ & $\begin{array}{l}\text { Kareler } \\
\text { Ortalama } \\
\text { sı }\end{array}$ & $\mathrm{F}$ & $\mathrm{p}$ & $\begin{array}{l}\text { Anlamlı } \\
\text { Fark }\end{array}$ \\
\hline $\begin{array}{l}\text { Teknoloji Kullanımına } \\
\text { ilişkin Tutumları }\end{array}$ & Gruplararası & .516 & 3 & .172 & .335 & .800 & \\
& Gruplariçi & 142.538 & 278 & .513 & & & \\
& Toplam & 143.054 & 281 & & & \\
\end{tabular}

Tablo-4'de Türkçe öğretmen adaylarının sınıf düzeyleri ile teknoloji kullanımına ilişkin tutumları arasında anlamlı bir fark olup olmadığına ilişkin bulgular yer almaktadır. Buna göre, Türkçe 
Türkçe Öğretmeni Adaylarının Eğitimde Teknoloji Kullanımına İlişkin Tutum ve Düşünceleri

öğretmen adaylarının sınıf düzeyleri ile teknoloji kullanımına ilişkin tutumları arasında anlamlı bir farklılık görülmemiştir $[F(.516-143)=.335, p>.05]$. Bu sonuca göre; öğrencilerin öğrenimlerine başladıkları ilk yıllardaki teknolojiye olan tutumlarının ilerleyen yıllarda aldıkları eğitimin etkisiyle herhangi bir değişime uğramadığını göstermektedir şeklinde yorum yapılabilir.

Tablo 5. Türkçe Öğretmeni Adaylarııın Mezun Olunan Lise Ile Teknoloji Kullanımına Ilişskin Tutumları Arasındaki iliş̧i

\begin{tabular}{llllllll}
\hline Alt Boyutlar & $\begin{array}{l}\text { Varyansın } \\
\text { Kaynağı }\end{array}$ & $\begin{array}{l}\text { Kareler } \\
\text { Toplamı }\end{array}$ & $\begin{array}{l}\text { Serbestlik } \\
\text { Derecesi }\end{array}$ & $\begin{array}{l}\text { Kareler } \\
\text { Ortalaması }\end{array}$ & F & p & $\begin{array}{l}\text { Anlamlı } \\
\text { Fark }\end{array}$ \\
\hline $\begin{array}{l}\text { Teknoloji Kullanımına } \\
\text { ilişkin Tutumları }\end{array}$ & Gruplararası & .344 & 3 & .115 & .223 & .880 & \\
& Gruplariçi & 142.710 & 278 & .513 & & \\
& Toplam & 143.054 & 281 & & & \\
\hline
\end{tabular}

Tablo-5'de Türkçe öğretmen adaylarının mezun oldukları lise türü ile teknoloji kullanımına ilişkin tutumları arasında anlamlı bir fark olup olmadığına ilişkin bulgular yer almaktadır. Araştırma bulgularına göre, Türkçe Öğretmeni adaylarının mezun olunan lise türü ile teknoloji kullanımına ilişkin tutumları arasında anlamlı bir farklılık olmadığı görülmüştür $[F(.344-143)=.223, p>.05]$. Öğretmen adayları teknoloji konusunda benzer şartlara sahip okullardan mezun olmuştur şeklinde yorum yapılabilir.

Araştırmanın üçüncü alt amacı, Türkçe öğretmeni adaylarının, eğitimde teknoloji kullanımına ilişkin sahip oldukları fikirleri tespit etmektir. Bu doğrultuda yapılan yarı-yapılandırılmış görüşmelere ilişkin bulgular Tablo-6' da gösterilmiştir.

Tablo 6. Türkçe Öğretmeni Adaylarıın Eğitimde Teknoloji Kullanımına Illişkin Düşünceleri

Görüşme Soruları $\quad$ Yanıtlara İlişkin Temalar

1. Size göre eğitimde kullanılan teknolojik araçlardan hangileri daha etkilidir?

- $\quad$ Bilgisayar çoğunlukta olmak üzere projeksiyon, tablet, flash, cd

2. Teknolojiyi eğitimde daha çok hangi amaçlarla kullanırsınız?

- Iş̧leri kolaylaştırması

- Öğrenmeyi kolaylaştırması

- Zaman avantajı

- Kullanabilme kolaylığı

- Dersi zevkli hâle getirmesi

- Dikkat çekmesi

- Öğretimde çeşitlilik 
Tablo 6. (Devamı) Türkçe Öğretmeni Adaylarının Eğitimde Teknoloji Kullanımına ilişskin Düşünceleri

\begin{tabular}{lll}
\hline Görüşme Soruları & Yanıtlara İlişkin Temalar \\
\hline $\begin{array}{l}\text { 3. Teknolojinin eğitimde kullanılmasının olumsuz } \\
\text { yönleri size göre nelerdir? }\end{array}$ & $\bullet$ Tembelliğe neden olması \\
& $\bullet \quad$ Öğretmenin teknoloji konusunda yeterli \\
& olmadığı durumlarda dikkat kaybı \\
& $\bullet$ Öğretim sürecini yavaşlatma \\
& $\bullet$ Ögretmenin teknoloji konusunda yeterli \\
& olmadığı durumlarda dersin kalitesi düşer
\end{tabular}

4. Eğitimde teknoloji kullanımına ilişkin yeterliklerinizin gelişmesi için, başka ne tür çalışmalar yapılabilir?
- Teknolojinin herkese ulaştırılması

- Kaynakların güncel olarak takip edilebilmesi için yabancı dil bilgisinin geliştirilmesi

- Öğretmen adaylarının teknoloji hakkındaki yeterliklerinin değerlendirilerek eksiklerin giderilmesi

- Teknoloji ve teknolojinin eğitimde kullanımı ile ilgili bilgilendirme amaçlı hizmetiçi eğitimler
5. Teknoloji ve eğitim kavramları arasındaki ilişkiyi bir metaforla açıklayınız.
- Teknolojinin yaşam boyu öğrenme için gerekliliği

- Teknoloji, eğitim seviyesinin yükselmesine yardımcı olan bir basamaktır

Türkçe Öğretmen adaylarının öğretimde teknoloji kullanımına ilişkin görüşlerinin olumlu olduğu görülmektedir. Öğretmen adayları çoğunlukla bilgisayar ve projeksiyonu eğitimde etkili olabilecek teknolojiler olarak görmektedirler. İşleri ve öğrenmeyi kolaylaştırması, zaman avantajı sağlaması, dikkat çekmesi ve öğrenmeyi zevkli hâle getirmesi gibi üstünlükleri öğretmen adaylarının teknolojiyi kullanma amaçlarının başında yer almaktadırlar. Teknolojinin eğitimde kullanılmasının olumsuz yönleri sorulduğunda ise çoğunlukla öğretmenlerin teknoloji konusunda yeterli bilgiye sahip olmadıkları ve okullardaki teknoloji desteğinin yetersiz olduğu yanıtlarına ulaşılmıştır. Öğretmen adayları, teknoloji ile eğitim arasındaki ilişkiyi, teknolojinin yaşam boyu öğrenme ve eğitim seviyesinin yükselmesi için gerekli olduğu yanıtı ile açıklamışlardır. 


\section{Sonuç ve Öneriler}

Bu çalışmanın amacı, Türkçe öğretmeni adaylarının öğretimde teknoloji kullanımına karşı tutum ve sahip oldukları fikirleri tespit edebilmektir. Araştırma sonucuna göre, Türkçe öğretmen adaylarının öğretimde teknoloji kullanımına ilişkin tutumlarının genel olarak olumlu olduğu ve kadın adayların erkeklere oranla daha olumlu tutuma sahip oldukları görülmüştür. Türkçe öğretmeni adayları ile benzer bir çalışma yapan Yaman (2007)'ın da benzer sonuçlara ulaşılarak kadın öğretmen adaylarının bilgisayar ve öğretim teknolojilerine erkeklere göre daha olumlu yaklaştığı görülmüştür. Bu doğrultuda öğretmenlik mesleğinde kadın adayların teknoloji desteği ile farklı öğretim tekniklerini kullanmaya daha ilgili oldukları düşünülebilir.

Türkçe öğretmen adaylarının "Sınıf Düzeyleri" ve "Mezun Olunan Lise" ile Teknoloji Kullanımına İlişkin Tutumları arasındaki ilişkiye bakıldığında ise anlamlı bir farklılık görülmemiştir. Bu doğrultuda katılımcıların mezun oldukları okulların teknoloji yönünden benzer şartlara sahip olduğu söylenebilir. Yavuz ve Coşkun (2008) ile Yılmaz, Ulucan ve Pehlivan (2010), yapmış oldukları çalışmalarda, teknoloji destekli proje çalışmaları sonucunda öğrencilerin öğretim faaliyetlerinde teknolojik araç gereç kullanımına ilişkin olumlu tutumlarının daha da arttığı sonucuna ulaşıımıştır. Yapılan bu araştırmanın sonucuna göre çalışmamıza katılan Türkçe öğretmen adaylarının sınıf düzeyleri ile tutumları arasında anlamlı bir fark bulunmaması nedeniyle, lisans eğitimleri süresince yeterli düzeyde teknoloji destekli çalışmalara katılmadıkları düşünülebilir.

Yapılan görüşmeler sonucunda Türkçe Öğretmen adayları öğretimde teknoloji kullanımına ilişkin görüşlerinin olumlu olduğu ve çoğunlukla bilgisayar ve projeksiyonu eğitimde etkili olabilecek teknolojiler olarak görmektedirler. Bu sonuca benzer bulgular Çuhadar ve Yücel'in (2010) yapmış oldukları araştırmada da görülmektedir. Bu araştırmanın sonuçlarına göre de; yabancı dil öğretmeni adaylarının çoğunluğu bilgisayar ve iletişim teknolojilerini öğretim amaçlı kullanma konusunda kendilerini yeterli görmektedirler. Teknolojinin eğitimde kullanılmasının olumsuz yönleri sorulduğunda ise çoğunlukla öğretmenlerin teknoloji konusunda yeterli bilgiye sahip olmamalarının ve okullardaki teknoloji desteğinin yetersiz olmasının sorun olabileceği görüşüne sahip oldukları görülmüştür. Bu olumsuzlukların giderilmesi için yapılabileceklerin temel olarak okullarda teknoloji desteğinin artırılması ve teknoloji konusunda bilgilendirici eğitimlerin düzenlenmesi gerektiği sonucuna ulaşılabilir. Ancak yapmış olduğumuz çalışmanın sonuçlarından farklı olarak, Karasaroğlu, Saraçoğlu ve Uça'nın (2011) yapmış oldukları çalışmada, Türkçe öğretmenlerinin teknolojiye yönelik tutumlarının çalıştıkları okulun sosyoekonomik düzeyine göre farklılık göstermediği görülmüştür. Okullardaki teknolojik yeterliliğin benzer seviyede olmasından dolayı öğretmenlerin bu şekilde 
düşündüklerini söylemek mümkündür. Bunun yanı sıra öğretmen adaylarının vermiş olduğu yanıtlar doğrultusunda teknoloji kullanımının artırılabilmesi için, güncel kaynakların takip edilmesini kolaylaştıracağından yabancı dil bilgisinin geliştirilmesinin de önemli olduğu söylenebilir.

Kaynakça

Büyüköztürk, Ş., Çokluk, Ö. ve Köklü, N. (2012). Sosyal bilimler için istatistik (10.baskı). Ankara: PegemAkademi Yayınevi.

Çelik, H. C. ve Kahyaoğlu, M. (2007). Ilköğretim öğretmen adaylarının teknolojiye yönelik tutumlarının kümeleme analizi. Türk Eğitim Bilimleri Dergisi, 5(4), 571-586.

Çuhadar, C. ve Yücel, M. (2010). Yabancı dil öğretmeni adaylarının bilgi ve iletişim teknolojilerinin öğretim amaçlı kullanımına yönelik özyeterlik algıları. Pamukkale Üniversitesi Eğitim Fakültesi Dergisi, 27, 199-210.

Erdemir, N., Bakırcı, H. ve Eyduran, E. (2009). Öğretmen adaylarının eğitimde teknolojiyi kullanabilme özgüvenlerinin tespiti. Türk Fen Eğitimi Dergisi, 6(3), 99-108.

Frankel, J. R., Wallen, N. E. \& Hyun, H. H. (2012). How to Design and Evaluate Research in Education (Eighth Edition). New York: McGraw Hill.

Karamustafaoğlu, O., Çakır, R.ve Topuz, F.(2012). Fen öğretiminde öğretmenlerin derslerinde materyal ve teknoloji kullanımına yönelik tutumlarının incelenmesi, $\mathrm{X}$. Ulusal Fen Bilimleri ve Matematik Eğitimi Kongresi. Niğde: Niğde Üniversitesi.

Karasakaloğlu, N., Saracaloğlu, S. A., Uça, S. (2011). Türkçe öğretmenlerinin teknoloji tutumları ile bilgi teknolojilerini kullanma düzeylerinin incelenmesi. Mersin Üniversitesi Eğitim Fakültesi Dergisi, 7(2), 26-36.

Karasar, N. (1999). Bilimsel araştırma yöntemi. Ankara: Nobel Yayın Dağııım.

Katrancı, M., Uygun, M. (2013). Sınıf öğretmenlerinin Türkçe derslerinde teknoloji kullanımına yönelik görüşleri. Adıyaman Üniversitesi Sosyal Bilimler Enstitüsü Dergisi Türkçenin Eğitimi Öğretimi Özel Sayısı, 6(11), 773-797.

Koehler, M. J., \& Mishra, P. (2005). What happens when teachers design educational technology? The development of technological pedagogical content knowledge. Journal of Educational Computing Redearch, 32 (2), 131-152.

Önkaş, N. A. (2008). Türkçe öğretiminde teknoloji kullanımı ve kalıı öğrenme. 8th. International Educational Technology Conference (ss.811-816), Eskişehir: Anadolu Üniversitesi.

Şahin, A. ve Akçay, A. (2011). Türkçe öğretmeni adaylarının bilgisayar destekli eğitime ilişkin tutumlarının incelenmesi. TurkishStudies- International Periodical for The Languages, Literature and History of Turkish or Turkic, 6(2), 909-918.

Yalın, H.i. (2003). Öğretim teknolojileri ve materyal geliştirme. Ankara: Nobel Yayınları.

Yaman, H. (2007). Türkçe öğretmeni adaylarının 'öğretim teknolojileri ve materyal geliştirme' dersi bağlamında Türkçe öğretiminde teknoloji kullanımına ilişkin yeterlilik ve algıları. İstanbul Üniversitesi Hasan Ali Yücel Eğitim Fakültesi Dergisi, 4(1), 57-71.

Yavuz, S. (2005). Developing a technology attitude scale for pre-service chemistry teachers. The Turkish Online Journal of Educational Technology - TOJET, 4, 1, 17-25.

Yavuz, S. ve Coşkun, A. E. (2008). Sınıf öğretmenliği öğrencilerinin eğitimde teknoloji kullanımına ilişkin tutum ve düşünceleri. Hacettepe Üniversitesi Eğitim Fakültesi Dergisi (H. U. Journal Of Education), 34: 276-286.

Yılmaz, i., Ulucan, H. ve Pehlivan, S. (2010). Beden eğitimi öğretmenliği programında öğrenim gören öğrencilerin eğitimde teknoloji kullanımına ilişkin tutum ve düşünceleri. $A h i$ Evran Üniversitesi Eğitim Fakültesi Dergisi, 11(1), 105-118. 